\title{
A Comparative Study of the Understanding of Undergraduates in the Knowledgebase on the Palm Leaf Manuscripts in Sri Lanka
}

\section{Bopeththe Somananda}

Department of Library and Information Science, Kelaniya University, Kelaniya, Sri Lanka

\section{Email address:}

Somanandabopeththe@gmail.com

\section{To cite this article:}

Bopeththe Somananda. A Comparative Study of the Understanding of Undergraduates in the Knowledgebase on the Palm Leaf Manuscripts in Sri Lanka. International Journal of Sustainability Management and Information Technologies. Vol. 7, No. 1, 2021, pp. 11-14. doi: 10.11648/j.ijsmit.20210701.12

Received: October 21, 2020; Accepted: November 9, 2020; Published: April 26, 2021

\begin{abstract}
The recent advances in the information and technology world, have transformed the role of local and foreign education sectors. When considering the local education system, it is clear that the indigenous qualities we have inherited from our ancestors should be preserved in an era of decay. Indigenous knowledge is far more spoken of and holds higher value than just knowledge itself. Across the world, special attention is focused not just on knowledge, but on indigenous knowledge. Therefore, it must be acknowledged that the words and the ideas of the indigene are of great importance. Indigenous knowledge, rather than traditional knowledge, is a cultural heritage of every human society. Thus, indigenous knowledge is specific to a particular geographical area. That indicates that, the knowledge possessed by the people living within a certain geographical area or region is their traditional knowledge or indigenous knowledge. Sri Lanka: a country which has an ancient history in writing traditions preserves its uniqueness through palm leaf manuscripts. It can be considered that palm leaf manuscripts have vastly contributed in the process of presenting the local historical knowledge from generation to generation. The Palm Leaf Manuscripts contain a wealth of knowledge related to various subject areas. The research asked whether Sri Lankan university students were aware of Palm Leaf Manuscripts. It examined the students' understanding on why Palm Leaf Manuscripts are a locally valued heritage that should be preserved. A sample of undergraduates from the Department of Library and Information Science, History and Archeology from the University of Kelaniya was obtained for this purpose. The main data collection instrument used was the questionnaire method, and primary data was collected through distributing the questionnaire to the undergraduates of each department using the random sampling method. Secondary data was collected through the printed sources which were considered relevant to the research. Data analysis showed that they had a general understanding of Palm Leaf Manuscripts.
\end{abstract}

Keywords: Palm Leaf Manuscripts, Indigenous Knowledge, University of Kelaniya, Undergraduates

\section{Introduction}

Palm-leaf manuscripts are one of the earliest forms of written media that bears a prominent place among the historical sources on Sri Lankan national cultural heritage [1] Until the advent of the printed papers, Palm-leaf Manuscripts served primary function on the Buddhist doctrine and canonical literature. The history of ancient Sri Lankan chirographic belongs to the arrival of Arahath Mahinda Thero [7].

'Mahindagamanaya' can be described as a turning point in the history of Sri Lanka. As a result of this, the art of writing in Sri Lanka has become widespread [14]. Earlier palm leaf manuscripts used to write commentaries. During the era of king Walagamba (89-77 BC), canonical commentaries were written down on palm leaves at Mathale Aloka Viharaya [13]. It added a new dimension to the Sri Lankan art of writing. With this state patronage, Sinhala writing art was developed in and around temples. The Pothgula (library) in these temples was nourished by Palm 
Leaf Manuscripts [10].

Old palm leaf manuscripts were mainly used in three main fields: religion, literature and practical science [9]. Accordingly, under the patronage of kings and the guidance of Buddhist monks' information that in form of Buddhist scriptures passed orally from generation to generation were documented, in the 1st century B. C [12].

Kotte era is known as the golden age of Palm Leaf Manuscripts writing. During this period a new set of Palm Leaf Manuscripts were written and a large number of Palm Leaf Manuscripts were copied [3]. Among them were religious, language literature, medicine, veterinary medicine, astrology, yantra mantra, fictions, customs and ceremonies, law, border (Kadima), story (Withthi), history, taxes and income, agriculture, state governance, Buddhist education, world detail and a large number of Palm Leaf Manuscripts on various subjects such as music and art [8].

The University of Kelaniya, which is the basis for this research, has a proud history of over 150 years. The Vidyalankara Pirivena which was established on 1st November 1875 AD has developed into the University of Kelaniya. Vidyalankara Pirivana gained the status of a University based on the Western Model in 1959 under the Universities Act No. 45 of 1958 [15]. Yet our academic heritage dates back to the beginning of Vidyalankara Pirivena

The faculty of social sciences was instituted in the academic year 1981/82. After the established this faculty, students had opportunity to study traditional disciplines like History, Archeology, Geography, Philosophy, Economics, Sociology, in addition the new subjects were added with the purpose of opening more job opportunities for graduates like Mass Communication, Library \& Information Science, Sport Science and Physical Education.

The Department of the Library and Information Science was established with the purpose of opening more job opportunities for graduates in the year 1973. The Department of History is one of the oldest Departments in the University of Kelaniya. It was initiated by the renowned historian Prof. Hem Chandra Ray. The Department of Archaeology has extended history from 1973 as a sub department under the Department of History. In 1977, the Department of Archaeology established as a separate department. Since its inception, the Departments have been working to educate students under the art of writing on Palm Leaf Manuscripts and Inscriptions.

With the advancement of technology in the world, discoveries have emerged. This has resulted in many changes in the local and foreign education sectors [11]. When it came to local education, it was clear that the indigenous qualities we inherited from the ancestors of the past should be preserved in an era of decaying age [9]. In this case, particular attention was paid to the nationally highly valued Palm Leaf Manuscripts. The Palm Leaf Manuscripts contained a wealth of local knowledge related to various subject areas [2]. The three Departments have created syllabuses to give knowledge to their students about Indigenous Knowledge and they in particular paid attention to the nationally highly valued Palm Leaf Manuscripts. Specially those three Departments were faced to update their students' knowledge about art of writing of the palm leaf manuscripts.

The problem of this research is, would the University students be aware of the need for preserving the Palm Leaf Manuscripts and their usefulness?

\section{Objectives}

1) The purpose is to Examining the understanding of the university students regarding the Palm Leaf Manuscripts which is containing the Indigenous Knowledge.

2) To examine the suitability of the Human Resources of University to update the society understands of Palm Leaf Manuscripts.

3) To examine the understanding of the university students about the cultural heritage of indigenous knowledge.

\section{Methodology}

This study was conducted as a comparative study of undergraduates for understanding about the palm leaf manuscripts. The population of this study was the University of Kelaniya three departments' students. They are the Departments of Library and Information science, Departments of History and Departments of Archaeology. The sample was selected as random, through the $90 \%$ confidence interval, adopting stranded Mathematical formula according to the Mood et al', applicable to stratified sampling.

$$
\begin{gathered}
n=\frac{\sum_{i=1}^{l} N_{i} p_{i} q_{i}}{N D+\frac{1}{N} \sum_{i=1}^{l} N_{i} p_{i} q_{i}} \\
n_{i}=n\left[\frac{N_{i}}{N}\right]
\end{gathered}
$$

Using this mathematical formula research sample was selected among the undergraduates of Department of Library and Information science, History and Archaeology, representing a total of four years' students, and a random questionnaire was distributed for them. Also, secondary and tertiary data were collected through the printed sources which was considered relevant to the research. The analysis and manipulating the collected data was done by using statistical analysis software.

\section{Results}

According to the findings of this study, it was revealed that most of the undergraduates of the three departments have General knowledge about the Palm Leaf Manuscripts. It percentage is more over $50 \%$. Compared to Department of Library and information science student's and undergraduates of other two departments, the students of the department of Library and information science have highly understanding 
about the palm leaf manuscripts and cultural heritage of indigenous knowledge. The reason for that, the department of library and information science has given their students, knowledge about the art of palm leaf in Sri Lanka by the syllabus.

At the research, the primary questionnaire was asked about the general understanding of the Palm Leaf Manuscripts from the sample data contributors. There were concerning the four academic years $96.22 \%$ of students with the said level of understanding and $3.77 \%$ had no ordinary understanding.

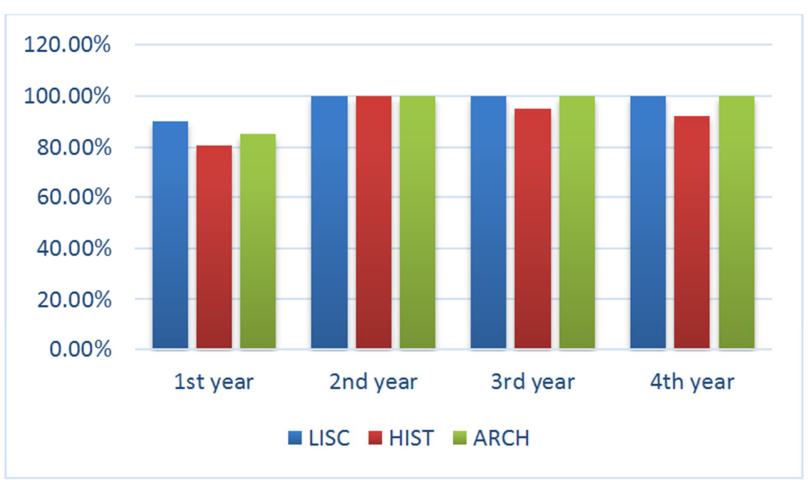

Figure 1. Undergraduates who have general knowledge about palm leaf manuscripts.

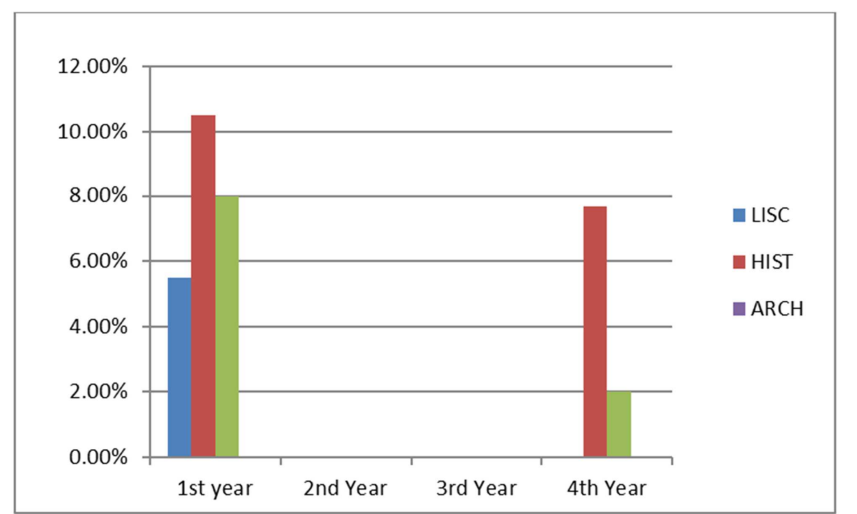

Figure 2. Undergraduates who don't have general knowledge about palm leaf manuscripts.

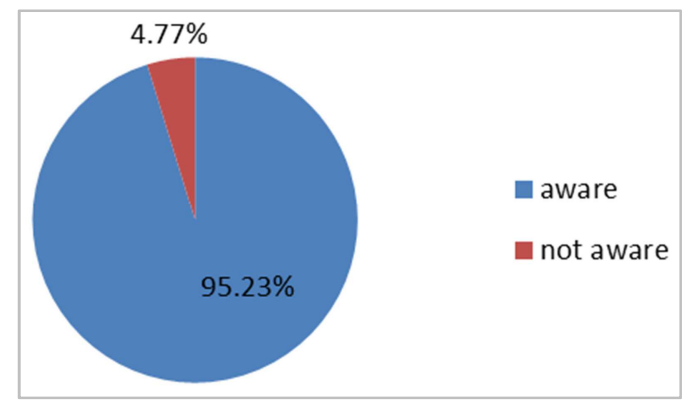

Figure 3. Awareness about the general knowledge of Palm leaf manuscripts.

Out of the respondents, $37.77 \%$ had reasonable knowledge on Database understanding of Palm Leaf Manuscripts usage and its context, the overall understanding of raw materials, design technology, and usage of Palm Leaf Manuscripts design, while $62.23 \%$ did not.

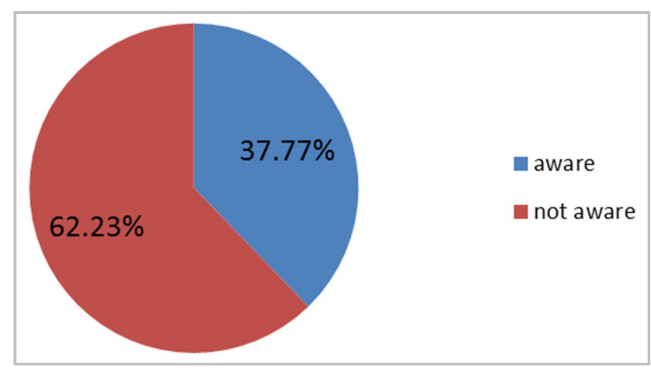

Figure 4. Awareness about design technology and usage.

Considering the knowledge on Palm Leaf Manuscripts preservation and conservation theories, as well as the awareness and understanding of databases of Palm Leaf Manuscripts conservation institutions, $35.23 \%$ of the students were aware, while $64.77 \%$ of the students did not understand that Palm Leaf Manuscripts should be preserved.

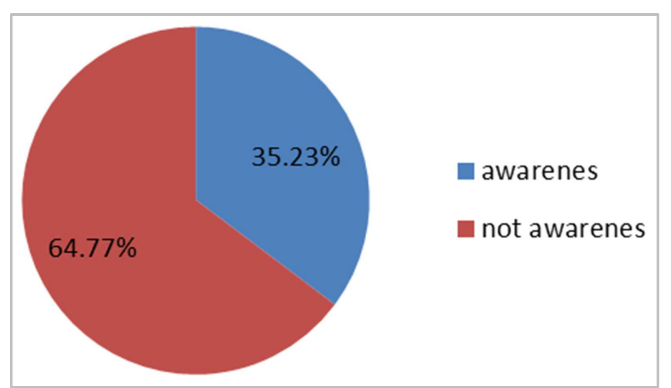

Figure 5. The sudents who have conservation knowladge about palm leaves.

\section{Conclusions}

1) The data also revealed that the majority of undergraduates in the Department Library and Information Science have a general understanding of Palm Leaf Manuscripts.

2) When looking at the percentage of total data contributors, it is evident that the second year, thirdyear and fourth-year undergraduates' general knowledge of Palm Leaf Manuscripts are always higher than in the first year undergraduates and it also means that undergraduates who study Library and Information Science and Archaeology have more understanding than the History undergraduates.

3) Most undergraduates do not know about the Palm Leaf Manuscripts design technology and of the materials used and their uses.

4) According to the data obtained, it was concluded that second -year Library and information science, and fourth - year Archaeology undergraduates have a deeper understanding of Palm Leaf Manuscripts. The main reason for this conclusion was their study on the conservation of and about Palm Leaf Manuscripts as a subject.

5) These Palm Leaf Manuscripts are a heritage to be conserved, and it is evident that there is considerable awareness among the Library and Information science and Archaeology undergraduates from the Department 
of conservation theories.

\section{Recommendations}

At present, Palm leaf manuscripts are of little importance. However, it is clear that Palm leaf manuscripts are rich in indigenous knowledge documented in the past (4). Some of the recommendations suggested, are based on the findings. They are as follows.

1) Organize programs to educate students of the entire university including the Department of Library and information science, History and Archaeology, on the national significance of the palm leaf manuscripts.

2) Organize awareness programs for students on palm leaf manuscripts preservation and providing practical training.

3) Launching National and International Research Seminar-Workshops on palm leaf manuscripts.

4) Establishing museums, research laboratories, and laboratories specializing in palm leaf manuscripts. Establishment of knowledge propagation centers and establishment of heritage in a systematic preservation manner.

5) Conducting awareness seminars and workshops to share knowledge about the cultural heritage of indigenous knowledge.

6) Should identify and develop a course to preserve and transverse the cultural heritage of indigenous knowledge to the new generation.

\section{References}

[1] Alahakoon, C. N. K. (2003). Management, conservation and preservation of palm-leaf manuscripts: a research study based on selected collections in Sri Lanka. Unpublished M. L. S. thesis. University of Colombo.

[2] Allepola, deepanjani, (2007), ThalpathLiweema, Central Cultural Fund, Department of Cultural Affairs, Colombo" Sri Lanka.

[3] Blackburn, Anne M. (2002). "Notes on Sri Lankan Temple
Manuscript Collections," Journal of the Pali Text Society XXVII: $1-59$

[4] Cabral, L. M. Udaya Prasad, Muthurajah Norman Ravikumar, and Thankavadivel Ramanan. (2018). "Developing a Strategic Program for Safeguarding Palm-Leaf Manuscripts in Sri Lanka." Kuala Lumpur, Malaysia, IFLA WLIC, August 24-30, 2018.

[5] Gunaratne, Mahendra. (2006). "Manuscript Writing on Palmleaves," "Man http://www.lankalibrary.com/phpBB/viewtopic.php?f=68\&t=2 873.

[6] Gunawardana, sirani (1997), palm leaf manuscripts of Sri Lanka, sarvodaya vishwaleka, Colombo.

[7] Kumar, D. Udaya, G. V. Sreekumar, and U. A. Athvankar. (2009). "Traditional Writing System in Southern India - Palm Leaf Manuscripts." Design Thoughts: 2-7.

[8] Lagamuwa, A., (2006), Art of writing palm leaf manuscripts in the Sri Lanka, Ministry of Cultural, Baththaramulla.

[9] Lagamuwa, āriya, (2006), Palm Leaf Manuscript Culture in Sri Lanka, Department of Cultural Affairs, Colombo. Sri Lanka.

[10] Ranasinghe, P. (2008). Preservation and Provision of Access to Indigenous Knowledge in Sri Lanka, World Library and Information Congress: 74th Ifla Conference and Council, Québec, Canada, [Online], Available at: https://archive.ifla.org/IV/ifla74/papers/106-Ranasingheen.pdf, [accessed on 04 June 2018].

[11] Ranasinghe, piyadāsa, (2010), Foreword of the An Annotated Bibliography of Palm Leaf Manuscripts in the Library in the Colombo national museum, Hettige NilanthaIndika, Department of National Museums"Colombo' Sri Lanka.

[12] Somadasa. K. D.(ed.) (1959-64) Lankave Puskola Pot Namavaliya, parts I and II, Colombo: Government Printers.

[13] Sumangala, H. \& Batuvantudave, P. (2015), Mahavanshaya sinhala, Buddhist Cultural Center: Dehiwala.

[14] Van Dyke, Yana. (2009). "Sacred Leaves: The Conservation and Exhibition of Early BuddhistManuscripts on Palm Leaves." The Book and Paper Group Annual 28: 83-97.

[15] Vidyodaya and Vidyalankara University Act No. 45, 1958, section 2 (1). 